\title{
PENGARUH CITA RASA DAN CITRA MEREK MIE SEDAAP TERHADAP MINAT BELI KONSUMEN DI TOKO CITRA JAYA KOTA SORONG
}

\author{
${ }^{*}$ Ayu Nilam Sari, ${ }^{2}$ Retno Dewi Wijiastuti \\ Universitas Muhammadiyah Sorong, Papua Barat, Indonesia \\ *ayuns040699@gmail.com
}

\begin{abstract}
Abstrak
Penelitian ini bertujuan untuk mengetahui pengaruh cita rasa dan citra merek mie sedaap terhadap minat beli konsumen di Toko Citra Jaya Kota Sorong. Metode yang digunakan adalah metode penelitian kuantitatif, Deskriptif, dan Korelasi. Hasil penelitian menunjukkan bahwa cita rasa berpengaruh signifikan terhadap minat beli konsumen dengan hasil uji hipotesis diperoleh $t$ hitung $>t$ tabel atau $(6,102>1,978)$. Citra merek berpengaruh signifikan terhadap minat beli konsumen dengan hasil uji hipotesis diperoleh $\mathrm{t}$ hitung $>\mathrm{t}$ tabel atau $(9,230>1,978)$. Cita rasa dan citra merek secara simultan berpengaruh signifikan terhadap minat beli konsumen dengan persamaan regresi $Y=12,689$ $+0,159 \mathrm{X} 1+0,613 \mathrm{X} 2$ dan kontribusi pengaruh sebesar 39,8\%,uji hipotesis diperoleh $\mathrm{F}$ hitung $>\mathrm{F}$ tabel atau $(44,322>3,06)$.
\end{abstract}

Kata Kunci: Cita Rasa, Citra Merek, Minat Beli, Mie Sedaap

\section{Abstract}

This study aims to determine the effect of taste and brand image of Sedaap noodles on consumer buying interest at Citra Jaya Stores, Sorong City. The method used is quantitative, descriptive, and correlational research methods. The results showed that taste had a significant effect on consumer buying interest with the results of hypothesis testing obtained $t$ count $>t$ table or $(6,102>1,978)$. Brand image has a significant effect on consumer buying interest with the results of hypothesis testing obtained $t$ count $>t$ table or $(9.230>1.978)$. Taste and brand image simultaneously have a significant effect on consumer buying interest with the regression equation $Y=$ $12.689+0.159 X 1+0.613 X 2$ and the contribution of the influence is $39.8 \%$, hypothesis testing is obtained $F$ count $>$ F table or $(44.322>3.06)$.

Keywords: Taste, Brand Image, Buying Interest, Mie Sedaap

\section{PENDAHULUAN}

PT Wings Group merupakan perusahaan yang memproduksi beberapa jenis makanan salah satu produk tersebut merupakan mie instan yang dikenal masyarakat dengan merek Mie Sedaap. Mie Sedaap merupakan salah satu merek mi instan yang populer di Indonesia yang memiliki varian cita rasa yang beragam serta memiliki isian yang lengkap dari segi bumbu serta isi yang lebih banyak, Perkembangan ekonomi di era-globalisasi sangatlah pesat. Mengakibatkan adanya persaingan dalam perdagangan bebas untuk merebut pangsa di dunia pemasaran Perusahaan kini diharuskan mampu bersaing dengan perusahaan lain (Rawi \& Civaningrum, 2019). Dalam hal itu Mie
Sedaap yang diluncurkan oleh PT Wings Group pada tahun 2003 di Indonesia, juga telah di pasarkan hingga ke luar negeri dikutip dari (Harahap, 2018).

PT Wings Group juga telah mendistribusikan produknya ke berbagai pelosok daerah di Indonesia termasuk salah satunya di kota Sorong. Seiring berkembangnya zaman pun menjadikan barang yang dikonsumsi ikut turut meningkat persediaannya. Para konsumen yang dihadapkan oleh banyaknya pilihan dari berbagai jenis dan macam barang adalah akibat dari meningkatnya jumlah dan kualitas barang-barang yang dikonsumsi secara terus menerus(Wangsi \& Rawi, 2018). Salah satu tempat yang menjual produk Mie Sedaap yaitu, Toko 
Citra Jaya Agen Grosir besar sembako di wilayah km 12 Kota Sorong, yang me nyediakan berbagai ragam sembako, dan salah satu produk yang ditawarkan adalah Mie Sedaap. Toko Citra Jaya memperoleh pasokan Mie Sedaap dari CV Kumbakarna wings distributor Mie Sedaap dikota Sorong, mie sedaap dikirim dari PT Wings Group ke gudang CV Kumbakarna wings dimana nantinya bagian kampas bertugas untuk membawa produk ke Toko Citra Jaya. Setiap daerah terdapat prinsipal yang merupakan utusan dari pabrik PT Wings Group yang bertugas untuk melaporkan kebutuhan atau berapa banyak persediaan atau stock yang dibutuhkan setiap daerah dan nantinya akan dikirim dari pabrik langsung lewat jalur udara ataupun laut.

Banyaknya jenis produk Mie Instant yang ada dengan berbagai cita rasa serta merek yang berbeda membuat perilaku konsumen berubah-ubah dalam menentukan pilihan dalam membeli produk karena semakin banyaknya pilihan produk mie instan. Hal tersebut adalah suatu perilaku konsumen yang dimaksud dengan Minat beli. Minat beli menurut (Durianto \& Darmadi, 2013) adalah keinginan untuk memiliki produk, minat beli akan timbul apabila seseorang konsumen sudah terpengaruh terhadap mutu dan kualitas dari suatu produk, informasi seputar produk.

PT Wings Group memproduksi beberapa ragam cita rasa khas yang berbeda dari setiap mie sedaap antara lain Mie Goreng Kriuk, Soto, Sambal Goreng, Ayam Bawang, Ayam Spesial, Kari Kental Spesial, Baso Spesial, White Kari, Sate, dan yang terbaru Mie Goreng Korean Spicy. Hal itu yang membuat mie sedaap memiliki kelebihan pada citarasanya yang tidak tertandingi dan harganya yang sangat terjangkau dibandingkan dengan produk sejenis yang dihasilkan oleh para Kompetitor (Rasyid \& Rawi, 2018). Setiap konsumen tentunya memiliki selera yang berbeda sehingga hal tersebut akan membuat konsumen memiliki banyak pilihan dalam menentukan minatnya membeli produk Mie Sedaap karena pilihan cita rasa yang beragam, sehingga dalam hal ini cita rasa menjadi salah satu variabel yang digunakan. Menurut (Drummond, 2010) cita rasa merupakan suatu cara pemilihan makanan yang harus dibedakan dari rasa makanan tersebut. Cita rasa merupakan atribut makanan yang meliputi penampakan, bau, rasa, tekstur, dan suhu.

Selain faktor Cita Rasa, Citra merek juga merupakan salah satu faktor yang mempengaruhi minat beli konsumen, Mie Sedaap merupakan merek mie instan yang telah banyak dikenal masyarakat akan tetapi berbagai merek mie instan lainnya telah banyak beredar di pasaran. Sehingga dalam hal ini persaingan antara citra suatu merek produk sangat penting karena citra merek yang baik dan tidak tentunya akan membuat pertimbangan konsumen terhadap minat beli. Menurut (Narjono, 2012) citra merek adalah apa yang konsumen pikirkan dan rasakan ketika mendengar atau melihat nama suatu merek.

Berdasarkan uraian diatas, maka peneliti tertarik mengambil judul "Pengaruh Cita Rasa dan Citra Merek Mie Sedaap terhadap Minat Beli Konsumen di Toko Citra Jaya Kota Sorong (Studi Pada Masyarakat Kota Sorong Wilayah KM 12)".

\section{METODE}

Jenis penelitian yang dipakai adalah deskriptif, Menurut Sugiyono (2017:29) penelitian deskriptif adalah metode penelitian deskriptif yang dilakukan untuk mengetahui keberadaan variabel mandiri, baik hanya pada satu variabel atau lebih (variabel yang berdiri sendiri atau variabel bebas) tanpa membuat perbandingan variabel itu sendiri dan mencari hubungan dengan variabel lainPopulasi dalam penelitian ini berjumlah 210 orang konsumen di Toko Citra Jaya.Teknik pengambilan sampel yang digunakan dalam penelitian ini menggunakan metode purposive sampling menurut (Notoatmodjo, 2010) adalah pengambilan sampel yang berdasarkan atas pertimbangan tertentu seperti sifat-sifat populasi ataupun ciri-ciri yang sudah diketahui sebelumnya. Adapun 
Karakteristik yang menjadi Sampel dalam penelitian ini yaitu konsumen yang membeli di Toko Citra Jaya, dan perhitungan untuk penentuan sampel dari populasi yang ada di ukur menggunakan rumus slovin sehingga jumlah sampel yang digunakan sebanyak 137 orang responden.

\section{HASIL PENELITIAN DAN \\ PEMBAHASAN}

\section{Analisis Deskriptif}

Pada pengujian ini digunakan untuk mengetahui skor minimum dan maksimum, mean score dan standar deviasi dari masing-masing variabel. Adapun hasilnya sebagai berikut:

Tabel 1. Hasil Analisis Descriptive Statistics

\section{Descriptive Statistics}

\begin{tabular}{ll|r|r|r|r} 
& N & Minimum & Maximum & Mean & Std. Deviation \\
\hline Cita Rasa (X1) & 137 & 15 & 15 & 30 & 3,289 \\
\hline Citra Merek (X2) & 137 & 14 & 16 & 30 & 3,437 \\
\hline Minat Beli (Y) & 137 & 21 & 19 & 40 & 3,901 \\
\hline Valid N (listwise) & 137 & & & & \\
\hline
\end{tabular}

Cita Rasa diperoleh varians minimum sebesar 15 dan varians maximum 15 dengan mean score sebesar 30 dengan standar deviasi 3,289.

Citra Merek diperoleh varians minimum sebesar 14 dan varians maximum 16 dengan mean score sebesar 30 dengan standar deviasi 3,437.

Minat Beli diperoleh varians minimum sebesar 21 dan varians maximum 40 dengan mean score sebesar 40 dengan standar deviasi 3,901.

\section{Analisis Verifikatif}

Pada analisis ini dimaksudkan untuk mengetahui pengaruh variabel independen terhadap variabel dependen. Adapun hasil pengujian sebagai berikut:

\section{a. Analisis Regresi Linier Berganda}

Uji regresi ini dimaksudkan untuk mengetahui perubahan variabel dependen jika variabel independen mengalami perubahan. Adapun hasil pengujiannya sebagai berikut:

Tabel 2. Hasil Pengujian Regresi Linier Berganda Coefficientsa

\begin{tabular}{|c|c|c|c|c|c|}
\hline \multirow[b]{2}{*}{ Model } & \multicolumn{2}{|c|}{$\begin{array}{l}\text { Unstandardized } \\
\text { Coefficients }\end{array}$} & \multirow{2}{*}{$\begin{array}{c}\text { Standardized } \\
\text { Coefficients } \\
\text { Beta }\end{array}$} & \multirow[b]{2}{*}{$\mathrm{t}$} & \multirow[b]{2}{*}{ Sig. } \\
\hline & $\mathrm{B}$ & Std. Error & & & \\
\hline 1 (Constant) & 12,689 & 2,161 & & 5,872 & ,000 \\
\hline Cita Rasa (X1) & 159 & 101 & 134 & 1,581 & ,116 \\
\hline Citra Merek (X2) & 613 & ,096 &, 540 & 6,365 & ,000 \\
\hline
\end{tabular}

a. Dependent Variable: Minat Beli (Y)

Berdasarkan hasil pengujian pada tabel di atas, diperoleh persamaan regresi $\mathrm{Y}=12,689+$ 0,159X1 + 0,613X2. Dari persamaan tersebut dijelaskan sebagai berikut:

1) Konstanta sebesar 12,689 diartikan jika cita rasa dan citra merek tidak ada, maka telah terdapat nilai minat beli konsumen sebesar 12,689 point.

2) Koefisien regresi cita rasa sebesar 0,159 , angka ini positif artinya setiap ada peningkatan cita rasa sebesar 0,159 maka minat beli konsumen juga akan mengalami peningkatan sebesar 0,159 point.

3) Koefisien regresi citra merek sebesar 0,613, angka ini positif artinya setiap ada peningkatan citra merek sebesar 0,613 maka minat beli konsumen juga akan mengalami peningkatan sebesar 0,613 point. 
b. Analisis Koefisien Determinasi

Analisis koefisien determinasi dimaksudkan untuk mengetahui besarnya persentase pengaruh dari

Tabel 3. Hasil Pengujian Koefisien Determinasi Cita Rasa dan Citra Merek Terhadap Minat Beli Konsumen

Model Summary

\begin{tabular}{|c|c|c|c|c|}
\hline \\
\hline Model & $\mathrm{R}$ & R Square & $\begin{array}{l}\text { Adjusted R } \\
\text { Square }\end{array}$ & $\begin{array}{l}\text { Std. Error of the } \\
\text { Estimate }\end{array}$ \\
\hline 1 & ,631 & ,398 & ,389 & 3,049 \\
\hline
\end{tabular}

Berdasarkan hasil pengujian diperoleh nilai determinasi sebesar 0,398 artinya cita rasa dan citra merek secara simultan memiliki kontribusi pengaruh sebesar 39,8\% terhadap minat beli konsumen, sedangkan sisanya sebesar $60,2 \%$ dipengaruhi faktor lain. variabel independen terhadap variabel dependen simultan. Adapun hasil pengujian sebagai berikut: c. Uji Hipotesis

Uji hipotesis Parsial (Uji t)

Pengujian hipotesis dengan uji $t$ digunakan untuk mengetahui hipotesis parsial mana yang diterima. Hipotesis pertama: Terdapat pengaruh yang signifikan antara cita rasa terhadap minat beli konsumen.

Tabel 4. Hasil Uji Hipotesis Cita Rasa Terhadap Minat Beli Konsumen.

\begin{tabular}{|c|c|c|c|c|c|c|}
\hline & & & oefficientsa & & & \\
\hline & & $\begin{array}{l}\text { Unstar } \\
\text { Coe }\end{array}$ & $\begin{array}{l}\text { dardized } \\
\text { ficients }\end{array}$ & $\begin{array}{c}\text { Standardize } \\
\mathrm{d} \\
\text { Coefficients }\end{array}$ & & \\
\hline & & B & Std. Error & Beta & $\mathrm{t}$ & Sig. \\
\hline & (Constant) & 17,768 & 2,284 & & 7,781 & ,000 \\
\hline & Cita Rasa (X1) & 551 & 090 & 465 & 6,102 & 000 \\
\hline
\end{tabular}

a. Dependent Variable: Minat Beli $(\mathrm{Y})$

Berdasarkan hasil pengujian pada tabel di atas, diperoleh nilai $\mathrm{t}$ hitung $>\mathrm{t}$ tabel atau $(6,102>1,978)$, dengan demikian hipotesis pertama

Tabel 5. Hasil Uji Hipotesis Citra Merek Terhadap Minat Beli Konsumen. Coefficients

\begin{tabular}{|c|c|c|c|c|c|c|}
\hline \multirow{2}{*}{\multicolumn{2}{|c|}{ Model }} & \multicolumn{2}{|c|}{$\begin{array}{l}\text { Unstandardized } \\
\text { Coefficients }\end{array}$} & \multirow{2}{*}{$\begin{array}{l}\text { Standardize } \\
\text { d } \\
\text { Coefficients } \\
\text { Beta }\end{array}$} & \multirow[b]{2}{*}{$\mathrm{t}$} & \multirow[b]{2}{*}{ Sig. } \\
\hline & & $\mathrm{B}$ & Std. Error & & & \\
\hline & (Constant) & 14,404 & 1,880 & & 7,664 & ,000 \\
\hline & Citra Merek (X2) & ,706 &, 076 & 622 & 9,230 & , 000 \\
\hline
\end{tabular}

a. Dependent Variable: Minat Beli $(\mathrm{Y})$

Berdasarkan hasil pengujian pada tabel di atas, diperoleh nilai $\mathrm{t}$ hitung $>\mathrm{t}$ tabel atau $(9,230>1,978)$, dengan demikian hipotesis kedua yang diajukan bahwa terdapat pengaruh yang signifikan atara citra merek terhadap minat beli konsumen diterima. yang diajukan bahwa terdapat pengaruh yang signifikan atara cita rasa terhadap minat beli konsumen diterima. 
beli konsumen.

Tabel 6. Hasil Uji Hipotesis Cita Rasa dan Citra Merek Terhadap Minat Beli Konsumen.

\begin{tabular}{|c|c|c|c|c|c|c|}
\hline \multirow[b]{2}{*}{ Model } & \multicolumn{6}{|c|}{ ANOVA $^{a}$} \\
\hline & & Sum of Squares & $\mathrm{df}$ & $\begin{array}{l}\text { Mean } \\
\text { Square }\end{array}$ & $\mathrm{F}$ & Sig. \\
\hline \multirow[t]{3}{*}{1} & Regression & 823,872 & 2 & 411,936 & 44,322 &, $000^{\mathrm{b}}$ \\
\hline & Residual & 1245,412 & 134 & 9,294 & & \\
\hline & Total & 2069,285 & 136 & & & \\
\hline
\end{tabular}

Berdasarkan hasil pengujian pada tabel di atas, diperoleh nilai $\mathrm{F}$ hitung $>\mathrm{F}$ tabel atau $(44,322>3,06)$, dengan demikian hipotesis ketiga yang diajukan bahwa terdapat pengaruh yang signifikan atara cita rasa dan citra merek terhadap minat beli konsumen diterima.

\section{PEMBAHASAN HASIL PENELITIAN}

1. Pengaruh Cita Rasa Terhadap Minat Beli Konsumen

Cita rasa berpengaruh signifikan terhadap minat beli konsumen dimana pada pengujian hipotesis pertama menghasilkan nilai koefisien regresi sebesar 0,159. Hal tersebut menunjukkan bahwa apabila nilai Cita Rasa (X1) mengalami peningkatan sebesar 1 satuan, maka nilai Cita Rasa Produk Mie Sedaap di Toko Citra Jaya Kota Sorong akan meningkat sebesar 0,159 satuan. Pengujian hipotesis diperoleh nilai $t$ hitung $>\mathrm{t}$ tabel atau $(6,102>1,978)$ dengan nilai signifikansi sebesar 0,000 lebih kecil dari pada 0,05. Dengan demikian hipotesis pertama yang diajukan bahwa terdapat berpengaruh signifikan antara cita rasa terhadap minat beli konsumen diterima.

2. Pengaruh Citra Merek Terhadap Minat Beli Konsumen

Citra Merek berpengaruh signifikan terhadap minat beli konsumen dimana pada pengujian hipotesis kedua menghasilkan nilai koefisien regresi sebesar 0,613. Hal tersebut menunjukkan bahwa apabila nilai Citra Merek (X1) mengalami peningkatan sebesar 1 satuan, maka nilai Citra Merek Produk Mie Sedaap di Toko Citra Jaya Kota Sorong akan meningkat sebesar 0,613 satuan. Pengujian hipotesis diperoleh nilai $\mathrm{t}$ hitung $>\mathrm{t}$ tabel atau $(9,230>1,978)$ dengan nilai signifikansi sebesar 0,000 lebih kecil dari pada 0,05. Dengan demikian hipotesis kedua yang diajukan bahwa terdapat berpengaruh signifikan antara citra merek terhadap minat beli konsumen diterima.

3. Pengaruh Cita Rasa dan Citra Merek Terhadap Minat Beli Konsumen

Cita Rasa dan citra merek berpengaruh signifikan terhadap minat beli konsumen dengan diperoleh persamaan regresi $Y=12,689+0,159 X 1+$ $0,613 \times 2$, hasil pengujian diperoleh nilai koefisien determinasi sebesar 0,398 artinya cita rasa dan citra merek secara simultan memiliki kontribusi pengaruh sebesar 39,8\% sedangkan sisanya sebesar $62,1 \%$ dipengaruhi faktor lain. Pengujian hipotesis diperoleh nilai $\mathrm{F}$ hitung $>\mathrm{F}$ tabel atau $(44,322>3,06)$ memiliki nilai probabilitas signifikansi 0,000 dimana nilai tersebut lebih kecil dari 0,05. Dengan demikian hipotesis ketiga yang diajukan bahwa terdapat berpengaruh signifikan antara cita rasa dan citra merek terhadap minat beli konsumen diterima.

\section{PENUTUP}

\section{Kesimpulan}

a. Cita rasa berpengaruh signifikan terhadap minat beli dengan hasil Uji hipotesis diperoleh nilai $\mathrm{t}$ hitung $>\mathrm{t}$ tabel atau $(6,102>1,978)$.

b. Citra merek berpengaruh signifikan terhadap minat beli dengan hasil Uji hipotesis diperoleh nilai $\mathrm{t}$ hitung $>\mathrm{t}$ tabel atau $(9,230>1,978)$.

c. Cita rasa dan citra merek secara simultan berpengaruh signifikan terhadap minat 
beli dengan kontribusi pengaruh sebesar $39,8 \%$ sedangkan sisanya sebesar $60,2 \%$ dipengaruhi faktor lain. Uji hipotesis diperoleh nilai $\mathrm{F}$ hitung $>\mathrm{F}$ tabel atau $(44,322>3,06)$.

\section{Saran}

a. Bagi peneliti dengan melakukan penelitian ini maka peneliti dapat mengetahui variabel Cita Rasa maupun Citra Merek berpengaruh terhadap Minat Beli di Toko Citra Jaya Kota Sorong.

b. Bagi Perusahaan yaitu PT Wings Group perusahaan yang memproduksi Mie Sedaap untuk lebih meningkatkan ataupun memperhatikan Cita Rasa dan Citra Merek dari produk Mie Sedaap yang dipasarkan kepada para konsumen , sehingga hal itu juga dapat meningkatkan Minat Beli konsumen pada toko Citra Jaya Kota Sorong yang mejual produk Mie Sedap, dimana hal tersebut tentunya akan sangat berdampak positif bagi minat beli konsumen di Toko Citra Jaya maupun PT Wings Group.

c. Bagi para peneliti selanjutnya bagi peneliti selanjutnya, agar dapat mempersiapkan diri dalam memulai penelitian dalam mengambil ataupun mengumpulkan data yang akan digunakan dan juga lebih memperluas dan mengembangkan kembali penelitian sehingga dapat diperoleh informasi yang lebih lengkap tentang hal-hal yang sangat berpengaruh pada Minat Beli konsumen, dan juga dapat mengembangkan penelitian ini dengan meneliti faktor lain yang mempengaruhi minat beli konsumen diluar variabel Cita Rasa dan Citra Merek.

\section{DAFTAR PUSTAKA}

Dharmayuni, L., et al.. (2021). Effect of Distribution Cost and Promotion Cost on Tyre Industries Sales Performance. Annals of the Romanian Society for Cell Biology, 12672-12684.
Drummond, K. E. (2010). Nutrition for foodservice andculinary professionals (J. Wiley \& Sons (ed.)). Inc.

Durianto, \& Darmadi. (2013). Strategi Menaklukan Pasar Melalui Riset Ekuitas danPerilaku Merek (cet. ke10). PT Gramedia Pustaka Utama.

Erlangga, H. (2021). Effect Of Digital Marketing And Social Media On Purchase Intention Of Smes Food Products. Turkish Journal of Computer and Mathematics Education (TURCOMAT), 12(3), 3672-3678.

Harahap, N. Z. (2018). Universitas Sumatera Utara 4. Pengaruh Kualitas Produk,Harga, Dan Promosi Terhadap Keputusan Pembelian Mie Instan Merek Mie Sedaap Pada Mahasiswa Asrama Putri Universitas Sumetra Utara, 1-105.

Mas'adi, M. (2018). Pengaruh Iklan, Kemudahan Penggunaan, Resiko Dan Citra Perusahaan Terhadap Minat Nasabah Internet Banking Bri Pada Nasabah Bri Unit Malabar Tangerang. JIMF (Jurnal Ilmiah Manajemen Forkamma), 2(1).

Narjono, A. I. (2012). Atribut Produk sebagai Dasar Pembelian Susu (Studi pada Swalayan Singosari Kabupaten Malang). Ekonomika Jurnal Ekonomi, 5(1):6-11.

Nurjaya, N., et al. (2020). Pengaruh Store Atmosphere Terhadap Keputusan Pembelian Konsumen Pada Starbucks Di Wilayah Cianjur. Jurnal Ekonomi Efektif, 2(4), 637-643.

Oktavia, E. (2020). Pengaruh citra merek dan kualitas produk terhadap minat beli komsumen pada pt. mayora indah tbk (studi kasus pada produk coklat choki choki).

Rasyid, N., \& Rawi, R. D. P. (2018). Pengaruh Bauran Pemasaran Terhadap Penjualan Pada Pt. Nestle Indofood Citarasa Indonesia Di Makassar. Sentralisasi, 7(2), 11-27.

Rasyid, N., et al. (2018). Pengaruh Bauran Pemasaran Terhadap Penjualan Pada PT. Nestle Indofood Citarasa 
Indonesia

$\mathrm{Di}$

Makassar. Sentralisasi, 7(2), 11-27

Rawi, R. D. P., \& Civaningrum, A. (2019).

PENERAPAN

STRATEGI

PEMASARAN

DALAM

MENINGKATKAN PENJUALAN CV

SENTOSA ABADI.

Setiawati, N. P. A., et al.. (2021). Effect of Technology Acceptance Factors, Website Service Quality and Specific Holdup Cost on Customer Loyalty: A Study in Marketing Departement of Packaging Industry. Annals of the Romanian Society for Cell Biology, 12685-12697.

Vony Novitasari Saputra, Awin Mulyati, S. A. (2015). Analisis Pengaruh Variasi Produk, Cita Rasa, dan Higienitas
Terhadap Minat Beli Konsumen (Studi Kasus Pada Ice Cream Zangrandi Surabaya). Jurnal.UntagSby.Ac.Id, 1-14. http://jurnal.untagsby.ac.id/index.php/adbis/article/v iew $/ 2322$

Wangsi, M. M., \& Rawi, R. D. P. (2018). Perlindungan Konsumen Dalam Pelabelan Produk Menurut Ekonomi Islam. Sentralisasi, 7(1), 1-9.

Yulistiana, I., et al. (2021). Did Brand Perceived Quality, Image Product And Place Convenience Influence Customer Loyalty Through Unique Value Proposition?. Journal of Contemporary Issues in Business and Government, 27(1), 2854-2867. 